\title{
Opracowanie naukowe Nowego Testamentu Jakuba Wujka T.J. wydanego w 1593 r.
}

\section{$\mathbf{K}$} siądz Jakub Wujek T.J. (1541-1597) jest autorem najbardziej znanego tłumaczenia Biblii na język polski. Przygotowane przez niego przekłady i kończąc jednocześnie epokę wielkich przekładów biblijnych. Jakub Wujek miał przed sobą olbrzymie żniwo prac translatorskich, które w szczególny sposób rozwinęły się i narosły w XVI w. Jego dzieło było szczytowym osiągnięciem w dziedzinie biblistyki humanistycznej, daleko odbiegającym od dotychczasowych prób pod tym względem, nie tylko krajowych, lecz i zagranicznych. Dokonał tłumaczenia $z$ łacińskiej Wulgaty i $z$ języków oryginalnych, posługując się piękną i poprawną polszczyzną. Jego przekład jest wierny, ale nie niewolniczy. Dzieło Jakuba Wujka należy do naszych bogactw narodowych. Równie wielkim osiagnięciem autora jest naukowe opracowanie przetłumaczonego tekstu. Mając tylu znakomitych poprzedników, którzy nadali tłumaczonym przez siebie tekstom nową postać wydawniczą, posiadlającą bogate wyposażenie i szereg ułatwień w korzystaniu $z$ tekstu, Jakub Wujek miał niewiele możliwości wprowadzenia całkiem nowych elementów do opracowania naukowego swojego przekładu. Jednak i pod tym względem jego dzieło przewyższa prace poprzedników.

Najbogatszy aparat naukowy zawiera Nowy Testament Jalkuba Wujka, wydany w Krakowie, w oficynie Andrzeja Piotrkowczyka, w 1593 r. Wszystkie elementy wchodzące w jego skład autor wymienił w tytule: „Nowy Testament Pana naszego Jezusa Chrystusa $z$ nowu $z$ lacińskiego i greckiego na polskie wiernie a szczyrze przelożony i argumentami abo summarijuszami każdych ksiąg i rozdziałów i annotacyjami po brzegach objaśniony. Przydane są nauki i przestrogi mało nie za każdym rozdziałem porównanie ewangelistów świętych dzieje i drogi rozmaite Piotra i Pawła świętego i rejestr rzeczy główniejszych na końcu"1. Annotacyje, przydatki lub przypiski, które Jakub Wujek zamieścił w przetłumaczonym przez siebie tekście Nowego Testamentu, możemy podzielić na dwie grupy. Pierwszą z nich stanowią annotacyje dłuższe, nazwane przez autora Nauki i przestrogi, które znajclują się po zakończeniu prawie każclego rozdziału. Do drugiej grupy należą annotacyje krótkie, umieszczone na marginesach. Te krótkie przypiski możemy również podzielić na dwie grupy. Do pierwszej zaliczymy annotacyje znajdujące się na marginesie zewnętrznym, do drugiej annotacyje, które Jalkub Wujek umieścił na marginesie wewnętrznym. Przypiskiznajdujące się na marginesie zewnętrznym bardzo dokładnie wskazują czytelnikowi wszystkie różnice pomiędzy łacińslą Wulgatą, tzw. wersją lowańską, która była podstawowym źródłem dla tłumacza - Biblia sacra. Quid in hac editione a Theologis Lovaniensibus praestitum sit, paulo post indicatur, wydaną w oficynie Krzysztofa Plantina w Antwerpii, w 1574 r., a oryginalnymi tekstami Nowe- 
go Testamentu i innymi wersjami łacińskimi. Oznaczając te tzw. varias lectiones Jakub Wujek jako pierwszy tłumacz katolicki zastosował znaki krytyczne, np. gwiazdkę, „rożenek”, dwie kreski, apostrof ${ }^{2}$. Znaczenie wszystkich wprowadzonych do tekstu symboli, wyjaśnił w znajdującej się po Przedmowie do czytelnika części, zatytułowanej Znakow rozmaitych ktore są w tych ksiegach wyłozenie. Wszystkie zastosowane znaki krytyczne podzielił na trzy grupy. Pierwszą z nich stanowią znaki uzyte „w samym telkście”, drugą występujące „w texcie y na brzegu”, trzecią znajdujące się „na samym brzegư ${ }^{3}$. W ten sposób ks. Wujek przedstawił czytelnikowi de facto dwa przekłady, z łacińskiej Wulgaty w tekście i $z$ oryginału greckiego na marginesach, gdzie jak najdokładniej pokazał wszystkie różnice między nim a Wulgatą. Korzystał z tekstu greckiego pochodzącego z Polyglotty Antwerpskiejzwanej tez Królewską - Biblia sacra. Hebraice, Chal daice, Graece et Latine. Philippi II Catholici pietate et studie..., wydanej w Antwerpii w oficynie Krzysztofa Plantina, w latach 1569-1572. Służące temu przypislki umieszczone na marginesach zewnętrznych możemy podzielic na trzy grupy. Pierwszą z nich stanowią annotacyje dotyczące wyrazów, których nie ma w Wulgacie, a znajdują się w tekście greckim. W takich przypadkach autor oznaczał odpowiednie miejsca w tekście symbolem gwiazdli. Taka sama gwiazdka występuje przy danym wersie na marginesie zewnętrznym, razem z duzą literą $G$ (wersja grecka) i brakującymi wyrazami. Druga grupa dotyczy wyrazów pominiętych w tekście oryginalnym, a występujących w Wulgacie. Takie przypadki tłumacz oznaczal znakiem nazwanym „rozenek”. Trzecia grupa przypisków dotyczy fragmentów tekstu różniących się w Wulgacie i w wersji greckiej. W takich przypadkach Jakub Wujek stosował znak „dwie kresce”. Na marginesach zewnętrznych i w tekście zaznaczył także początek i koniec perykop lekcyjnych i ewangelicznych, przeznaczonych na poszczególne nieclziele i święta. Początek czytania i święto, którego ono dotyczy opisane jest na marginesie, koniec czytania sygnalizuje umieszczony $w$ tekście znak rączki. Symbolem, który najczęściej spotykamy „w samym texcie” jest kluczyk. Oznacza on początek każdego wiersza. Obok na marginesie autor jodaje jego liczbę. W celu rozpowszechnienia swojego przekładu, Jalkub Wujek wprowadził podział rozdziałów według obrządku wschodniego, zaznaczając na marginesie zewnętrznym tak zwane zaczała, skrótem Zacz lub Zacza. Jednym ze sposobów naszego tłumacza, które miały słuzyć kształtowaniu jasnego i poprawnego tekstu tłumaczonego, było wprowadzanie do niego dodatkowych wyrazów, nieobecnych w źródle podstawowym. Wyrazy takie autor wyróżnił w tekście czcionką kursywną o mniejszym stopniu. Znakiem dwu kresek zaznaczył ks. Wujek w tekście miejsca, które uważał za trudne i w związku z tym wymagające dodatkowego wytłumaczenia, które razem z takim samym znakiem umieścił na marginesie zewnętrznym. Annotacyje zawierające takie dodatkowe informacje często przybierały postać definicji encyklopedycznych. Autor tłumaczył w ten sposób terminy i realia biblijne. Zależało mu na przyblizeniu czytelnikowi obcej kultury. Często objaśniał przejmowane, obce wyrazy np. poprzez odnoszenie ich do rodzimych nazw. Marginesy wewnętrzne ks. Wujek podzielił na dwie rubryki. W węższej z nich, przylegającej do tekstu, znajdują się liczby i duze litery. Liczby oznaczają kolejne wiersze rozdziałów Ewangelii, Dziejów Apostol- 
skich i Listów. Kolejne litery alfabetu dzielą rozdziały na mniej więcej równe ustępy. W drugiej rubryce szerszej zaznaczone zostały konkordancje ${ }^{4}$.

Inną kategorię objaśnień, zastosowanych przez Jakuba Wujka w tłumaczonym tekście Nowego Testamentu, stanowią annotacyje dluższe, nazwane przez autora Nauki i przestrogi. Znajdują się one na końcu prawie każdego rozdziału. To bardzo dokładne i obszerne objaśnienia miejsc trudniejszych, zwłaszcza tych, które niezgodnie $z$ nauką Kościoła katolickiego interpretowali innowiercy. Często mają charakter polemiczny, a ton oskarżycielski i emocjonalny. W wielu przypadkach Nauki i przestrogi bywają dłuższe od komentowanego tekstu. Przygotowując tak obszerne objaśnienia, ks. Wujek wykorzystał ogromną ilość dowodowego tekstowego materiału. Posługiwał się najlepszymi znanymi wówczas tekstami i objaśnieniami do Ksiąg świętych. Za najbardziej poprawny tekst, uważano Wulgate, opracowaną przez teologów lowańskich, wydrukowaną w Antwerpii, w 1574 r. Wydanie to, nie było jeszcze ściśle naukowe, ponieważ nie uwzględniało wszystkich odmiennych lekcji języka oryginału. Uzupełnienie pod tym względem stanowiła praca Eukasza z Brügge, wydana w oficynie Krzysztofa Plantina w Antwerpii, w 1580 r. Nationes in Sacra Biblia quibus variantia discrepantibus exempla loca summo studio, auctore Francisco Luca Brugense $S$. Theologiae Licentiato. Ks. Wujek korzystał z tekstu greckiego, pochodzącego z Poliglotty Antwerpskiej, zwanej także Królewską, wydrukowanej w Antwerpii, u Krzysztofa Plantina, w latach 1569-1572. Nowy Testament znajclowal się tam w języku greckim, łacińskim i syryjskim. Osobne wydanie Nowego Testamentu, ukazało się w 1583 r. Jakub Wujek korzystał także z tekstów wydanych przez Erazma $z$ Rotterdamu Teodora Bezę i tekstu Nowego Testamentu opracowanego przez Roberta Stefanusa Novum Testamentum graecunn cum duplici interpretatione Desiderii Erasmi et veteris interpretis, harmonia item evangelica et copioso indiee, wydanego w 1551 r., w Genewie. Material do komentarzy czerpał z objaśnień Ojców i Doktorów Kościoła, z późniejszych zaś z Roberta Bellarmina. Wiele skorzystał $z$ uwag egzegetycznych zamieszczonych w Nowym Testamencie wydanym przez angielskich katolików w Reims we Francji, w 1582 r. Różnica między przekładem Nowego Testamentu dokonanym przez Jakuba Wujka a przekładami sporządzanymi przez innowierców, uzewnętrznia się głównie w komentarzach i glosach marginesowych, zaś o wiele mniejszym stopniu w samym tekście kanonicznym.

Bardzo ważnym elementem opracowania naukowego Nowego Testamentu Jakuba Wujka, wydanego w 1593 r., są tak zwane sumnny, które dzisiaj możemy nazwać streszczeniami. Słuzyły one lepszemu zrozumieniu Pisma św., ułatwiały prace $z$ tekstem i posługiwanie się samą księgą. Wprowadzały w treść kolejnych ksiag Nowego Testamentu i przygotowywały czytelnika do lektury. Po podanym przez autora Porządku ksiag Nowego Testamentu, zamieszczona została Summa Nowego Testamentu. Jakub Wujek wymienił cztery główne części Nowego Testamentu, wraz z krótkim wyjaśnieniem co znajduje się w każdej z nich. Dalej znajduje się Suma czterech Ewangeliey. Autor przedstawil postacie ewangelistów - św. Mateusza, św. Marka, św. Łukasza i św. Jana, oraz krótkie wyjaśnienie dotyczące treści czterech Ewangelii. Dokładniejsza analiza została dokonana w kolejnej części, zatytułowanej Summa y porządek Historyey Ewangeliey świetey, za czterech Ewangelistow zebrany, y na swe czéści 
y lata, ktorych sie co działo rozdzielony. Ks. Wujek przedstawił w 199 punktach, ułożonych w porządku chronologicznym, wszystkie najważniejsze wydarzenia opisane przez ewangelistów, począwszy od narodzin Chrystusa do Jego wniebowstąpienia. Lewy margines podzielił na cztery rubryki, z których każcla odpowiadla jednemu ewangeliście. Przy każdym punkcie znajdują się w owych rubrykach cyfry. Dzięki nim czytelnik latwo mógł się zorientować, który ewangelista, i w którym rozdziale opisuje dane wydarzenie. Na przyklad punkt 111 to: "Zmartwychwstanie dnia trzeciego" ${ }^{5}$. Zapis na marginesie mówi o tym, że każdy $z$ ewangelistów opisał to wydarzenie, św. Mateusz $w$ rozdziale 28, św. Marek w rozdziale 16, św. Łukasz w rozdziale 24, a św. Jan w rozdziale 20. Każdą Ewangelię, oraz każdą część Ewangelii, i każdy kolejny rozdział również poprzedzają Summy. Analogicznie Dzieje Apostolskie poprzedza Argument, abo Summa Dzieiów Apostolskich, a każdy rozdział tej części Nowego Testamentu zaczyna się od Summy rozdziału. Ks. Wujek napisał: „A ponieważ Dzieie Apostolskie, dwu przednieyszych Apostolow Piotra y Pawla S. sprawy opisuia, zdało mi się za potrzebna, Summę spraw obydwu, na dwu tabliczkach osobnych tu na końcu przydać" ${ }^{6}$. Zgodnie $z$ tym, po Dzicjach Apostolskich autor zamieścil kolejno: Summę Dzieiów Piotra S. Apostoła i Summę Dzieiów Pawła S. Apostola. Spisał tu najważniejsze wydarzenia z życia św. Piotra i św. Pawła. Po lewej stronie znajdują się przylegające do tekstu trzy rubryki. W pierwszej Jakub Wujek podal rok „za ktorego Cesarza panowania co się działo”. W drugiej rubryce określił datę „naznaczywszy ktorego roku po Narodzeniu (Chrystusa)”. W trzeciej rubryce znajduje się data opisanego obok wyclarzenia „po W niebo wstąpieniu Pańskim"7. Oto przyklad z Summy Dzieiów Pawła S. Apostoła: „Szaweł prześladuje kościół Boży, Podawaiąc do więzienia męże y niewiasty" "Zapisy dokonane przez ks. Wujka w rubrykach po lewej stronie tekstu, informują czytelnika, że wydarzenia te miały miejsce w 19 r. panowania cesarza Tyberiusza, a 35 r. po narodzeniu Chrystusa i 2 r. po wniebowstappieniu Pańskim. Kolejną częścią Nowego Testamentu są Listy św. Pawła i Listy pisane przez innych apostołów, zwane Listami powszechnymi. Są one najtrudniejszym w odbiorze i zrozumieniu fragmentem Nowego Testamentu, stąd Jakub Wujek poprzedził je obszernym wstępem, zatytulowanym Sprawa i Lisciech Apostolskich. Każdy kolejny List poprzedza Argument albo Summa listu, a każdy rozdzial Summa rozdziału. Ostatnią część Nowego Testamentu, czyli Apokalipsę św. Jana, autor konsekwentnie poprzedzil Summą Obiawienia S. Jana, a każdy rozdzial Summą rozdziatu.

Po wszystkich księgach Nowego Testamentu Jakub Wujek umieścił clwa regestry. Pierwszy z nich to Regestr abo Tablica Epistol y Ewangeliy, ktore z Nowego Testamentu wyięte, w Niedziele y w Swięta, y w Posty w kościele wedlug zwyczaiu rzymskiego czytaią. Na każdej stronie w dwu kolumnach, zostały spisane wszystkie niedziele i święta kościelne, oraz inne dni wraz z odpowiadającymi im perykopami lekcyjnymi i ewangelicznymi ze wskazaniem, na której stronie czytelnik może je odnaleźć. Drugi to Regestr abo spisek słow y rzeczy przednieyszych, ktore się $w$ tym Nowym Testamencie y w Annotacyach iego zamykaią. W dwu kolumnach, w porządku alfabetycznym, autor spisał najważniejsze jego zdaniem osoby, rzeczy, nazwy geograficzne i inne pojęcia występujące w tekście Pisma św. oraz w annotacyach. Obok podał wyjaśnienia 
wraz $z$ oznaczeniem gdzie w tekście występują dane słowa. Regestry przygotowane przez ks. Wujka odpowiadają dzisiejszym indeksom w opracowaniu naukowym tekstu. Na samym końcu znajduje się errata, którą autor zatytułował Omylki szkodliwsze tak poprawisz. We wszystkich księgach Nowego Testamentu tłumacz zastosował żywą paginę. Jakub Wujek poprzedził Nowy Testament wydany w 1593 r. obszerną Przedmową do czytelnika. Przedstawił w niej metody i techniki pracy przekłaclowej jakie zastosował, wymienił wybrane przez siebie teksty źródłowe, wraz ze szczegółowym uzasadnieniem, zapoznał czytelnika ze swoim warsztatem naukowo-badawczym i bardzo dokładnie omówił zastosowany aparat naukowy. Wiele miejsca autor poświęcił polemice $z$ innowiercami polskimi i zagranicznymi.

Nowy Testament Jakuba Wujka, wydany w 1593 r., był pierwszym w Polsce naukowo opracowanym przekładem telistu Pisma św. pochodzącym z obozu katolickiego. Oceniając opracowanie naukowe Nowego Testamentu przygotowane przez ks. Wujka, nie możemy brać za podstawę dzisiejszych osiągnięć na tym polu. Punktem odniesienia powinien być stan ówczesnej biblistyki katolickiej i krytyki tekstu. Analizując dokładnie wszystkie elementy wchodzące w skład aparatu naukowego znajdującego się w Nowym Testamencie Wujka z 1593 r., dochodzimy do wniosku, że opracował on tłumaczony tekst w sposób profesjonalny i prawdziwie naukowy, przewyższając swoich poprzedników i odbiegając daleko od dotychczasowych prób pod tym względem. Ksiądz Walenty Prokulski T.J. napisał: „A $\dot{z}$ do dzieła Władyslawa Szczepańskiego T.J.: «Cztery Ewangelie» (1917) jest przekład ks. Wujka z r. 1593 jedynym prawdziwie naukowo opracowanym i wydanym Nowym Testamentem, jaki Polska dotąd miała" ${ }^{9}$.

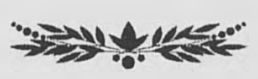

\section{Przypisy:}

${ }^{1}$ Karta tytułowa Nowego Testamentu Ks. Wujka z 1593 r. (w transkrypcji), w: Nowy Testament w przekladzie ks. Jakuba Wujka z roku 1593, (wyd. foto-typ.), Kraków 1966, s. XLIX.

${ }^{2}$ Symbole sygnalizujące $w$ tekście istniejące jego odmiany, były cechą charakterystyczną wydań krytycznych tekstów biblijnych, a pod koniec XVI w. nie były zjawiskiem nowym. Szeroko weszły w użycie już w połowie XVI w. Stosowal je Erazm z Rotterdamu, Robert Estienne, Crispinus, Teodor Beza. Występują w Biblii Kompluteńskiej, drukowanej w latach 1514-1517. Pierwszym polskim tłumaczem, który wprowadzil nowy typ wydawnictwa biblijnego, opatrując tekst przekładu w znaki krytyczne, byl Stanisław Murzynowski. W Nowym Testamencie wydanym w latach 15511553, zastosował pięć symboli krytycznych. Szymon Budny wprowadził do swoich przekładów tylko trzy symbole: nawiasy, gwiazdki i pochyłe znaki równania. Znaki krytyczne zastosowal także Marcin Czechowicz w Nowym Testamencie wydanym w 1577 r. Były to: krzyżyki, „klamberki”, gwiazdki, listki. J. Czerniatowicz, Niektóre problemy nankowe w pracach biblistów polskich XVI $i$ XVII w., Wrocław 1969, s. 68-69. 
${ }^{3} \mathrm{~J}$. Wujek, Znakow rozmaitych ktore sa w tych ksieggach wylozenie, w: Nowy Testament w przekladzie ks. Jakuba Wujka z roku 1593, (wyd. foto-typ.), Kraków 1966, s. 2830.

${ }^{4}$ Po raz pierwszy wiersze do Starego Testamentu wprowadzil dominikanin Santes Pagninus w Biblii wydanej w Lyonie, w 1528 r. Podziału Nowego Testamentu na wiersze dokonał Robert Estienne i zastosował go w wydaniu tekstu grecko-lacińskiego Nowego Testamentu, z $1551 \mathrm{r}$. W Polsce pionierami tego ważnego ułatwienia w korzystaniu z tekstu byli tłumacze Biblii Brzeskiej, wydanej w 1563 r. Podział tekstu na wersy zastosował także Marcin Czechowicz i Szymon Budny. Ten ostatni po raz pierwszy nazwał poszczególne odcinku tekstu rozdziałami, które poprzednio zwano kapituły. Spośród polskich thumaczy Pisma św., nazwę taką przejął od Szymona Budnego tylko Jakub Wujek. Od tego momentu wyraz rozdzial znalazl powszechne zastosowanie w języku polskim i jest używany po dzień dzisiejszy. Po raz pierwszy Pismo św. podzielił na rozdziały Stefan Langthon, kardynał i arcybiskup z Cantenluury, zmarły w $1228 \mathrm{r}$. W 1262 r. dominikanin Hugo a Sancto Varo podzielil rozdziały na siedem równych ustępów, które oznaczyl pierwszymi literami alfabetu. Był on także wynalazcą konkordancji do Pisma św. Wśród polskich tłumaczy Biblii konkordancje oznaczyli Stanisław Murzynowski, Szymon Budny, Marcin Czechowicz, oraz tłumacze katoliccy w Nowym Testamencie Scharffenbergera, z 1556 r. i Biblii Leopolity z 1561 r. W. Smereka, Przedmowa do czytelnika, w: Nowy Testament w przekładzie ks. Jakuba Wujka z roku 1593, (wyd. foto-typ.), Kraków 1966, s. XL, LXX.

${ }^{5} \mathrm{~J}$. Wujek, Summa y porządek Historyey Ewangeliey świętey, ze czterech Ewangelistow zebrany, y na swe części y lata, ktorych się co dzialo, rozdzielony, [w:] Nowy Testament w przekladzie ks. Jakuba Wujka z roku 1593, (wyd. foto-tyj.), Kraków 1966, s. 40.

${ }^{6} \mathrm{~J}$. Wujek, Nowy Testament w przekladzie ks. Jakuba Wujka z roku 15.93. (wyd. fototyp.), Kraków 1966, s. 509.

${ }^{7}$ Ibidem, s. 509.

${ }^{8} \mathrm{~J}$. Wujek, Summa Dziejów Pawła S. Apostoła, w: Nowy Testament w przekładzie ks. Jakuba Wujka z roku 1593, (wyd. foto-typ.), Kraków 1966, s. 512.

${ }^{9}$ W. Prokulski, Wiekoponnne dzieło. W 350 rocznice wydania Biblii Wujka, „Przegląd Powszechny" 1949, t. 228, s. 271. 